\title{
Link between reproductive output and larval supply of a common damselfish species, with evidence of replenishment from outside the local population
}

\author{
J. L. McIlwain ${ }^{1,2, *}$ \\ ${ }^{1}$ Australian Institute of Marine Science, PO Box 264, Dampier 6713, Western Australia, Australia \\ ${ }^{2}$ Zoology Department, University of Western Australia, Crawley 6907, Western Australia, Australia
}

\begin{abstract}
The link between reproductive output and larval supply is described for a common damselfish species Pomacentrus vaiuli in tropical Western Australia. I monitored the reproduction of 2 groups of $P$. vaiuli that occupied slightly different habitats. Egg clutches laid on artificial substratum were quantified on a bi-weekly basis during the consecutive spawning seasons of 1994/95 and 1995/96. The timing of egg production was similar for both groups and showed a distinctly semi-lunar pattern. The majority of the larvae hatched during the period when flood tide occurred $2 \mathrm{~h}$ either side of sunset. At Ningaloo this only happens during neap tides when the tidal amplitude is at its minimum. However, this means that larvae are dispersed nocturnally when the risk of predation is minimal. No relationship was found between egg production and changes in water temperature. Spawning ended prematurely for 1 of these groups of fish following the passing of a tropical cyclone within $80 \mathrm{~km}$ of the coast. Larval supply of $P$. vaiuli was estimated in the vicinity of the reproductive sites by capturing pre-settlement fish at one of these locations (Tantabiddy), and post-settlement fish at the other (Bundegi). The arrival of $P$. vaiuli larvae to Tantabiddy was on a lunar cycle with periodicities between 28 to $30 \mathrm{~d}$. When these larval supply data were lagged by the average pelagic duration of $22 \mathrm{~d}$, and then cross-correlated with the spawning data, there was a weak relationship. At Bundegi, I constructed recruitment patterns and estimated the birth dates of juveniles, using otolith analysis. By back-calculating the birth dates of individual fish that settled at Bundegi I made 2 discoveries. Firstly, most juveniles from 1994/95 hatched when spawning output at Bundegi was low, and secondly, more than $50 \%$ of fish caught in 1995/96 hatched after the spawning season had ended prematurely. This suggests that many of the juvenile $P$. vaiuli that settled at Bundegi during the second summer were not produced by this population but from elsewhere. I discuss the likelihood that larvae arriving to Ningaloo are from adult populations which inhabit fringing reefs to the north and that the observed patterns in larval supply are the result of an interaction between both physical and behavioural processes.
\end{abstract}

KEY WORDS: Larval supply $\cdot$ Coral reef fish $\cdot$ Recruitment $\cdot$ Lunar cycle $\cdot$ Ningaloo $\cdot$ Damselfish Spawning

Resale or republication not permitted without written consent of the publisher

\section{INTRODUCTION}

Far from being random events, the release of sexual propagules by coral reef organisms is often highly

${ }^{*}$ Present address: Department of Marine Science \& Fisheries, Sultan Qaboos University, PO Box 34, Al-Khod, Sultanate of Oman 123. E-mail: mcilwain@squ.edu.om synchronised with environmental parameters such as lunar cycles, tidal height and moonlight levels (Babcock et al. 1986, Babcock 1995, Danilowicz 1995a). Coral reef fish that spawn pelagic larvae are no exception. For example, tropical damselfish may display a variety of spawning patterns ranging from protracted, year-round, daily events (Robertson 1990) to limited, discrete events restricted to specific seasons (e.g. sum- 
mer; Meekan 1992). Within spawning seasons reproductive output is often synchronised with the lunar cycle. Reproductive cycles are often site- and speciesspecific and may include low-frequency lunar cycles (de Boer 1978, Schmale 1981, Robertson et al. 1990), higher-frequency cycles (e.g. semi-lunar or $<14 d_{\text {i }}$ Ross 1978, Doherty 1983, Moyer et al. 1983) or even acyclic frequencies of varying period lengths (Stanton 1985, Danilowicz 1995, Tyler \& Stanton 1995). However in the latter case, recent studies have cited other environmental variables as the underlying mechanisms responsible for patterns in fecundity such as tidal conditions (Foster 1987), fluctuations in plankton abundance (Tyler \& Stanton 1995), and changes in water temperature (Danilowicz 1995).

For some fish populations that exhibit lunar spawning cycles, these patterns are often preserved in the daily settlement records of juveniles (Meekan et al. 1993, Robertson et al. 1999). Several studies have tested the settlement-linkage hypothesis indirectly by comparing daily patterns in damselfish egg production with settlement patterns lagged by mean larval duration. Two of these studies found lunar patterns in settlement driven by the timing rather than the magnitude of production (Robertson et al. 1988, Meekan et al. 1993). A third, which used identical techniques, found no such relationship. Instead recruitment of Dascyllus albisella at Oahu Island was not coupled with local spawning output (Danilowicz 1997). In all 3 cases, planktonic processes acted to dilute the influence of spawning cycles by introducing substantial temporal variation in replenishment patterns (Doherty 1991).

With the recent development of several new sampling techniques (Doherty 1987, Dufour \& Galzin 1993, Shenker et al. 1993, Sponaugle \& Cowen 1996, Kingsford \& Finn 1997), monitoring replenishment patterns of reef fish on a daily basis is possible in nearly all coral reef settings. The topography of Ningaloo Reef, Western Australia, is suitable for lengthy deployments of stationary reef 'crest' nets, which catch a rich diversity of larval fish (Doherty \& Mcllwain 1996). Here I present results on the magnitude and variability of reproductive output and replenishment patterns in 1 species of damselfish common to this region and caught as larvae in the crest nets. Understanding the timing of recruitment of reef fish on the west coast of Australia is especially pertinent given that mass spawning and recruitment of scleractinian corals takes place in March and April (Simpson 1991). This is 4 to 5 mo after the same event on the east coast, where fish recruitment peaks concurrently with coral spawning (Babcock et al. 1986, Pitcher 1992, Meekan et al. 1993). The specific objective of this study is to test whether the periodicity in larval production from the Ningaloo region of Western Australia is linked to larval supply. Furthermore, I discuss whether these populations fit either of the models proposed earlier. These are (1) that the timing of production drives that of larval supply (Robertson et al. 1988, Meekan et al. 1993) or (2) larval replenishment is sourced from an external spawning population (Danilowicz 1997).

\section{MATERIALS AND METHODS}

Study sites and sampling strategy. Spawning output by Pomacentrus vaiuli was studied in the region of North West Cape over 2 breeding seasons, 1994/95 and 1995/96. Two sites were chosen at each of 2 locations: Ningaloo Reef near Tantabiddy and Bundegi Reef within Exmouth Gulf (Fig. 1). The 2 groups of adult $P$. vaiuli at the Tantabiddy sites $(1.2 \mathrm{~km}$ apart) resided in the shallow lagoon (2.5 to $4 \mathrm{~m}$ depth) and were situated over contiguous reef. Both sites were dominated by plating corals (live and dead colonies), particularly Acropora hyacinthus and Acropora cytharea, interspersed with large Porites patch reefs. The Bundegi group of $P$. vaiuli was also located over continuous reef dominated by acroporid corals but in slightly deeper water (5 to $8 \mathrm{~m}$ ). Reproductive data were collected from 2 Bundegi sites separated by a distance of about $1 \mathrm{~km}$.

Quantifying reproductive output. Standard spawning surfaces were used to measure spawning periodicity in Pomacentrus vaiuli. At the beginning of the spawning season the natural nests of a number of $P$. vaiuli males were replaced with terracotta roofing tiles $(40 \mathrm{~cm} \times 20 \mathrm{~cm})$. Previous studies from the Great Barrier Reef have shown this material to be highly successful in providing a suitable spawning surface for several species of pomacentrid (Doherty 1983, Meekan et al. 1993, Kerrigan 1997). At both locations, the majority of male $P$. vaiuli accepted the artificial substrate and resumed courtship behaviour and rigorous site defence within minutes of placing the tiles.

A total of 15 males was chosen from each site at both locations. Census of the reproductive output began as soon as the artificial nesting sites were established. On each visit, a chinagraph pencil was used to trace the outline of each clutch onto a sheet of clear plastic placed over the tile. The term 'clutch' refers to an individual egg mass regardless of the number of contributing females. Estimating the developmental age of individual clutches was determined early in the first season by visiting several clutches every day and recording the degree of eye pigmentation. Clutches laid on the first day had transparent eyes, which gradually developed pigment 


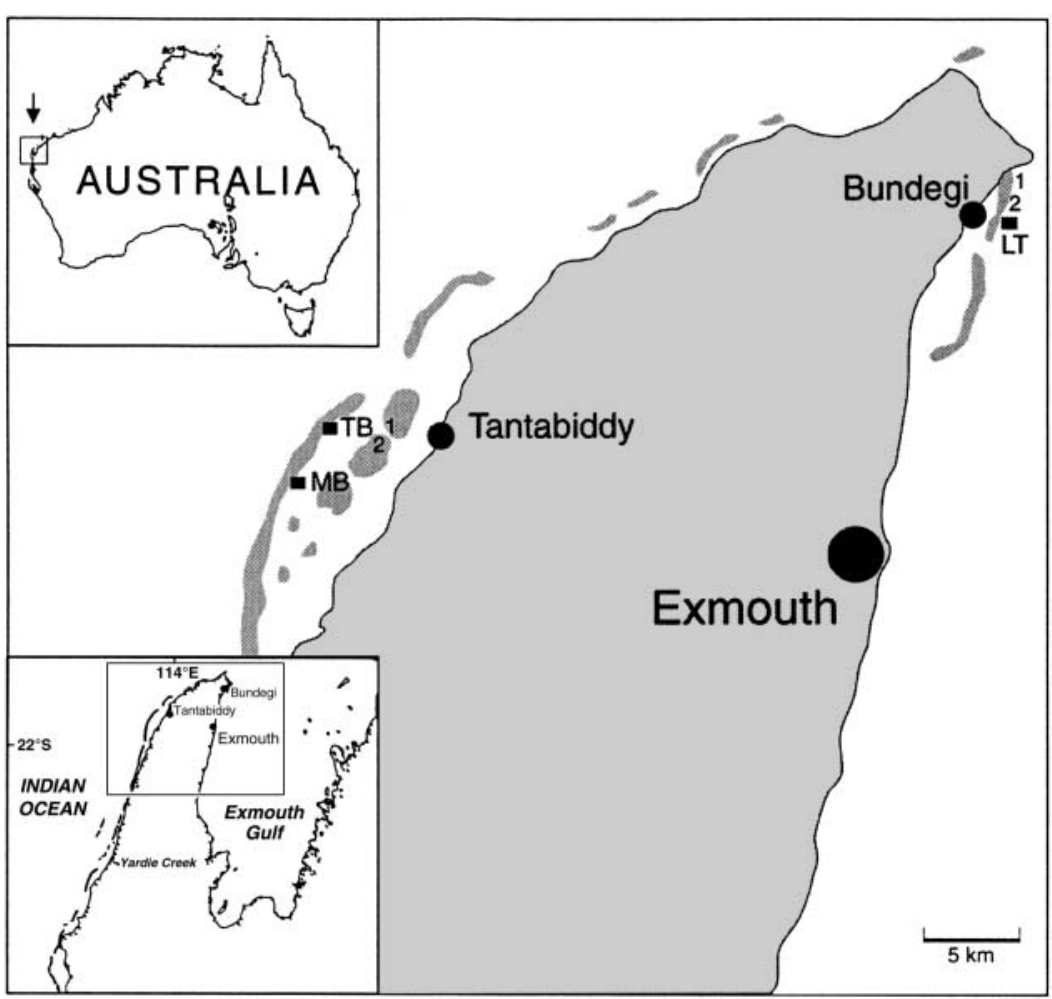

Fig. 1. The primary study sites at Tantabiddy and Bundegi and their position relative to the peninsula which forms the North West Cape and Exmouth Gulf (lower panel). Sites 1 and 2 are the artificial nest sites at the 2 locations. TB (Tantabiddy) and MB (Mangrove Bay) denote the position of the crest net pairs at Tantabiddy

with age, until on the last day before hatching the eyes were silver. This daily change in pigmentation enabled ageing of Pomacentrus vaiuli clutches deposited outside of the census days. Once the average time for embryonic development was established at $5.5 \mathrm{~d}$, nests were censused every second or third day. This ensured that no eggs were laid and hatched between visits.

Environmental variables. The number of new nests deposited every day was correlated with daily maximum tidal amplitude and daily maximum water temperature to examine whether reproductive output varied with environmental variables. Tidal data were obtained from the National Tidal facility at Flinders University, Adelaide, and daily water temperature data were collected with a WESDATA 891 single channel logger which was deployed at $4 \mathrm{~m}$ depth at Osprey Bay, approximately $18 \mathrm{~km}$ south of Tantabiddy, for a $23 \mathrm{mo}$ period covering the study period (M. Mackie unpubl. data). The Osprey Bay data were considered suitable as a comparison of these data with Tantabiddy temperature readings because 6 of the months revealed no significant difference between the 2 sites $\left(T_{2,18}=1.45, \mathrm{p}=\right.$ $0.16)$. Water temperature readings were also collected from Bundegi during the second summer with a Hobo data logger programmed to take 6 water temperature readings each day from 14 November 1995 to 14 February 1996.

Estimating patterns in larval supply and recruitment. Presettlement Pomacentrus vaiuli larvae were captured as they crossed the reef near Tantabiddy using the crest net techniques described by Doherty \& McIlwain (1996). Between 4 October 1994 and 16 March 1995 a pair of crest nets, 500 m apart, were deployed on the shallow reef flat approximately $80 \mathrm{~m}$ behind the primary surf zone (Fig. 1, TB). The following year between 11 November 1995 and 5 March 1996 an additional 2 nets, also spaced $500 \mathrm{~m}$ apart, were deployed $5 \mathrm{~km}$ to the south at Mangrove Bay (Fig. 1, MB). Each morning between 08:00 and 10:00 $\mathrm{h}$ the cod-end was emptied and the sample preserved in $5 \%$ formalin in seawater. A total of 94 samples were collected in the first year and 101 in the second. At a later date the larvae were sorted from the catches and identified under a dissecting microscope to family categories following the references of Leis \& Rennis (1983) and Leis \& Trnski (1989).

Otolith analysis. The analysis of otoliths from juvenile and presettlement Pomacentrus vaiuli had 2 objectives: firstly, to construct recruitment patterns at Bundegi; and secondly, to establish larval duration. To achieve these objectives, as many size categories as possible of newly settled fish were collected at Bundegi, once during the latter part of the first summer and monthly over a 3 mo period during the second. Although all 3 otolith pairs were removed, growth increments were much clearer in the lapilli than in the sagittae and asteriscus. Otolith sectioning procedures followed those of Wilson \& McCormick (1997) and increments were counted under a compound microscope at $400 \times$ and $1000 \times$ magnification.

Increments were assumed to be laid down on a daily basis as in the congeners Pomacentrus moluccensis (Pitcher 1988), P. wardi (Pitcher 1988) and P. coelestis (Thorrold \& Milicich 1990). The settlement check was difficult to see in every one of the fish processed. In these I used the change in increment width technique developed in sparids but not validated in pomacentrids, to determine the date of settlement (Vigliola et al. 2000). Comparison of profiles of otolith increment width with the growth of 10 presettlement fish caught 
in light-traps deployed at Bundegi indicated a distinct decline in otolith width 2 to $3 \mathrm{~d}$ prior to settlement. This transitional period of low growth just prior to settlement was used as a proxy settlement mark to calculate the average pelagic duration.

Data analysis. Reproductive output of Pomacentrus vaiuli was analysed by time series techniques and repeated measures ANOVA. The periodicity in reproductive output was quantified by spectral analysis using the periodogram technique to define where in the time series most of the energy was concentrated (Thorrold et al. 1994). To meet the minimum requirement of approximately 4 lunar cycles per time series (Chatfield 1980), the 2 seasons of sampling effort were concatenated for each location (Milicich 1992). As further evidence of cycling, auto-correlation plots of the raw data were examined. Finally, the reproductive data were cross-correlated with an artificially generated semi-lunar cycle (Robertson et al. 1988) to define the point in the lunar cycle where reproductive activity peaked (Meekan 1992).
Before cross-correlation techniques were applied to daily spawning output and physical parameters, serial dependency was removed by fitting ARIMA (autoregressive integrated moving average) models (e.g. $1,1,0)$. The choice of model was determined after examining the auto-correlation plots. The residuals from these models were used in the cross-correlation analysis. Similarly, the relationship between the timing of reproductive output and larval supply was examined using cross-correlation analysis following the same procedure. Prior to analysis, the larval supply data were lagged by the average pelagic duration determined by counting the otolith increments (Meekan et al. 1993). This time series was then crosscorrelated with the spawning data, which had been lagged by the average developmental period of $5.5 \mathrm{~d}$ rounded to $5 \mathrm{~d}$ (see above in 'Quantifying reproductive output'). For periods when no data were collected, the missing data points were interpolated from 5 adjacent points (Milicich 1994).
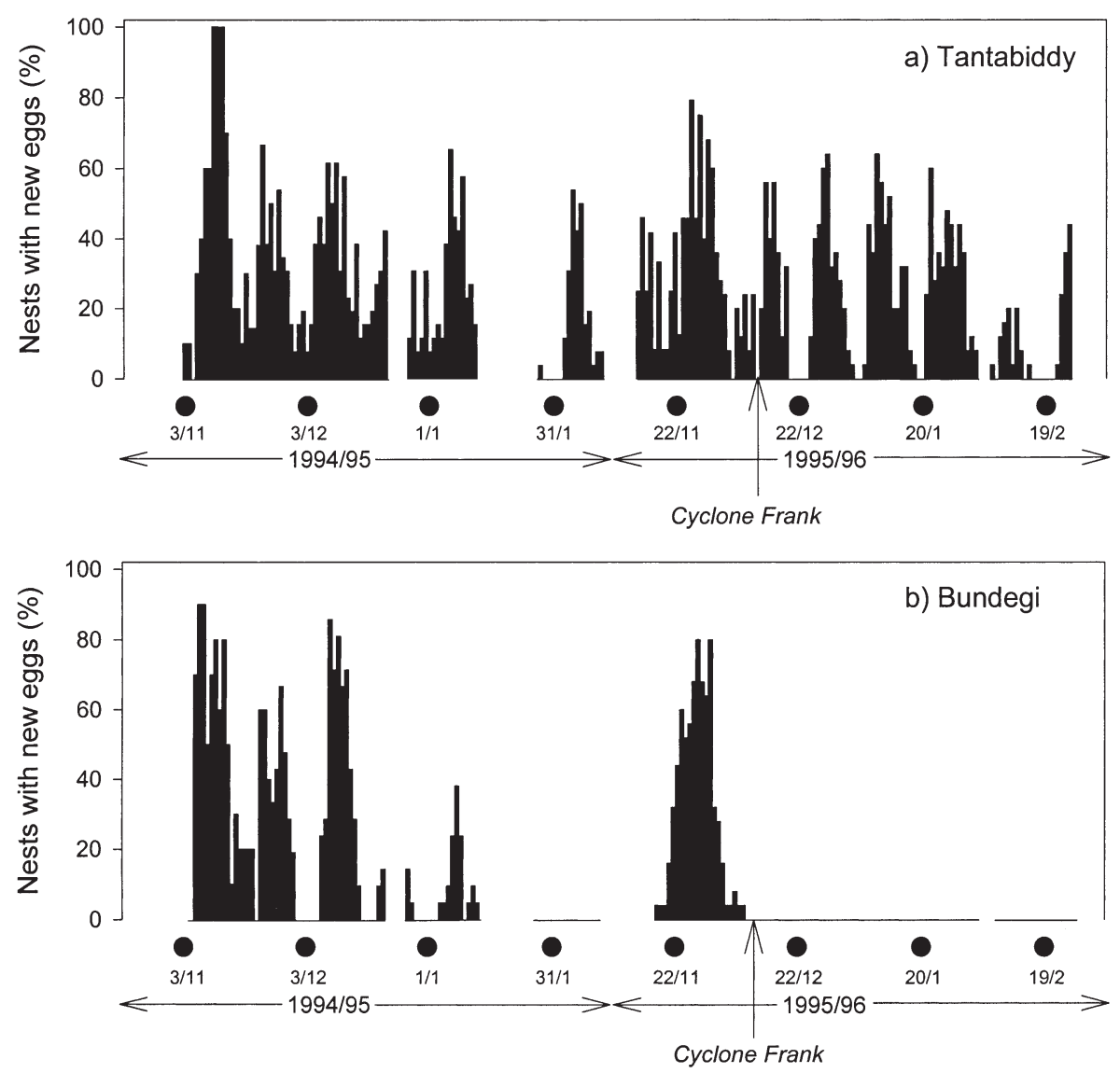

Fig. 2. Time series of the percentage of nests that had new egg clutches for each day of sampling at (a) Tantabiddy and (b) Bundegi during 2 summers. Lunar representation: $\bullet$ new moon with dates on which these occurred. Gaps on the $x$-axis denote missing data points. Data have been concatenated in order to fulfil the requirements of the spectral analysis. The day on which Cyclone Frank passed within $70 \mathrm{~km}$ of the coast has also been noted 
A repeated measure, nested ANOVA design on 11 randomly chosen nests at each site was used to compare spawning output among sites and between locations and years. Nests included in the analysis must have been in place in both years. This included those tiles missing at the start of the second year but replaced by new tiles placed in the same position (this occurred 4 times).

\section{RESULTS}

\section{Cyclone activity}

During the sampling period 7 cyclones passed through an area $600 \times 600 \mathrm{n}$ miles, encompassing the North West Cape and Ningaloo regions (Shepard \& Bate 1997). These accounted for a total of 23 cyclone days, 5 in the first season and 18 the following year (Callaghan 1997). This inter-annual difference in the number of cyclones was attributed to a rather weaker than normal summer monsoon during the 1994/95 season which was driven by strong El Niño activity (Shepard \& Bate 1997). Of the 7 cyclones, only 2 came close to Ningaloo Reef. The most destructive, Cyclone Frank, passed within $70 \mathrm{~km}$ of North West Cape on 11 December 1995, had a maximum intensity of $945 \mathrm{hPa}$, producing destructive winds up to $31 \mathrm{~m} \mathrm{~s}^{-1}$ (Callaghan 1997). North-easterly winds created by the clockwise motion of the cyclone produced a $3 \mathrm{~m}$ storm surge in Exmouth Gulf (Callaghan 1997). Cyclone Jacob developed later in the same season (February 1996), reaching a maximum intensity of $955 \mathrm{hPa}$ when it was $150 \mathrm{~km}$ from North West Cape (Callaghan 1997).

\section{Periodicity in reproductive output}

Highest egg production for both populations occurred early in both years (Fig. 2a,b). However because spawning was already in progress when nest tiles were first placed, reproductive output may in fact occur earlier than November. Periodicity in egg laying was variable. At Bundegi in 1994/95 and Tantabiddy in
1995/96, spawning stopped for short periods (up to 7 d) and in 1995/96, following the passing of Cyclone Frank on 11 December, spawning stopped completely with the exception of a single clutch laid in late January (Fig. 2b). The cessation of spawning was confirmed when several surveys along the continuous reef at Bundegi in the following months failed to find any new clutches.

At Tantabiddy in 1994/95, clutches were laid continuously for periods up to $60 \mathrm{~d}$ (Fig. 2a). In contrast, spawning in the following year was not continuous. The strong winds and large swell generated by Cyclone Frank had minimal impact at Tantabiddy, suspending spawning activity for a brief $24 \mathrm{~h}$ period when the cyclone was closest to the coast (Fig. 2a).

Although the length of the season and the continuity of egg production differed between locations and seasons, the periodicity of reproductive output was the same. At both locations during both years, peaks in egg production occurred on a semi-lunar cycle as determined by spectral analysis and the auto-correlation plots (Table 1). The exact timing of these peaks was established by comparing reproductive output with a generated semi-lunar phase (Table 1). There was some variation to the exact day on which these peaks occurred depending on the location and year. For example, at Tantabiddy in 1994/95 the peak in clutch numbers was $3 \mathrm{~d}$ before and after the new and full moons, compared with $3 \mathrm{~d}$ before and $5 \mathrm{~d}$ after at Bundegi. During the second year at Tantabiddy this changed slightly, with peaks occurring $2 \mathrm{~d}$ before and $5 \mathrm{~d}$ after each full moon.

\section{A comparison of spawning output between sites, locations and years}

The results of the repeated measures ANOVA revealed a location difference in the mean number of eggs clutch $^{-1}$. There were fewer eggs clutch ${ }^{-1}$ at the Bundegi sites than the Tantabiddy sites across both years (Table 2, Fig. 3a,b). The mean number of eggs clutch ${ }^{-1}$ at Bundegi was approximately 2500 to 2700 compared to nearly 3400 at the second site at Tantabiddy. Also egg

Table 1. Summary of the spawning output at both locations for each of the 2 yr using auto-correlation function plots (ACF) and cross-correlation with an artificial lunar cycle (Lunar). Values in each of these columns are the lag (in d) and the corresponding r values. ${ }^{*}$ Significant at $2 \times \mathrm{SE}$

\begin{tabular}{|c|c|c|c|c|c|c|c|c|}
\hline \multirow[t]{2}{*}{ Location } & \multicolumn{4}{|c|}{ 1994/95 } & \multicolumn{4}{|c|}{$1995 / 96$} \\
\hline & $\mathrm{ACF}$ & $\mathrm{r}$ & Lunar & $\mathrm{r}$ & $\mathrm{ACF}$ & $\mathrm{r}$ & Lunar & $\mathrm{r}$ \\
\hline Tantabiddy & 14 & $0.34^{*}$ & $-3,3$ & $0.41^{*}, 0.32^{*}$ & 15 & $0.44^{*}$ & $-2,5$ & $0.31^{*}, 0.32$ \\
\hline Bundegi & 15 & $0.26^{*}$ & $-3,5$ & $0.37^{*}, 0.32^{*}$ & - & - & - & - \\
\hline
\end{tabular}


Table 2. Summary of the repeated measures ANOVA of both the mean eggs per clutch and total number of clutches of 44 nests from 2 sites at each of the 2 locations, Tantabiddy and Bundegi, during 2 spawning seasons. The analysis was performed on nontransformed data meeting the assumptions of normality. ${ }^{*} p<0.05$. For the within clutches factor the results of the MANOVA, which does not depend upon the sphericity assumption (Zar 1996) have been presented. See Fig. 3a-d for the corresponding means at the 2 sites at Tantabiddy and Bundegi during 1994/95 and 1995/96

\begin{tabular}{|c|c|c|c|c|c|c|}
\hline \multirow[b]{2}{*}{ Source } & \multicolumn{3}{|c|}{ Mean eggs per clutch } & \multicolumn{3}{|c|}{ Total number of clutches } \\
\hline & $\mathrm{df}$ & F & $\mathrm{p}$ & df & F & $\mathrm{p}$ \\
\hline \multicolumn{7}{|l|}{ Among years } \\
\hline Location & 1 & 6.266 & $0.016^{*}$ & 1 & 11.50 & 0.077 \\
\hline Site (Location) & 2 & 0.265 & 0.768 & 2 & 5.38 & $0.008^{*}$ \\
\hline Residual & 40 & & & 40 & & \\
\hline \multicolumn{7}{|l|}{ Within years } \\
\hline Year & 1 & 1.178 & 0.284 & 1 & 0.066 & 0.799 \\
\hline Year $\times$ Location & 1 & 0.0007 & 0.9810 & 1 & 12.086 & $0.001^{*}$ \\
\hline Year $\times$ Site (Location) & 2 & 1.908 & 0.162 & 2 & 7.893 & $0.001^{*}$ \\
\hline
\end{tabular}

clutches were smaller at this site in the first summer compared with those mapped in the second season. The greater fecundity of this group at Site 2 was reflected in the significantly greater mean total clutches spawned at the same site in the second summer (Table 2, Fig. 3c), and also produced a significant interaction effect. Even though spawning stopped prematurely at Bundegi resulting in fewer clutches for the season (Fig. 3d), those that were laid had similar numbers of eggs to clutches spawned the year before (Fig. 3b).

\section{a) Tantabiddy}

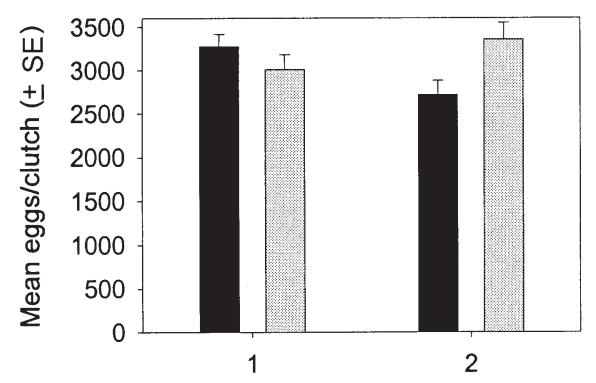

c) Tantabiddy

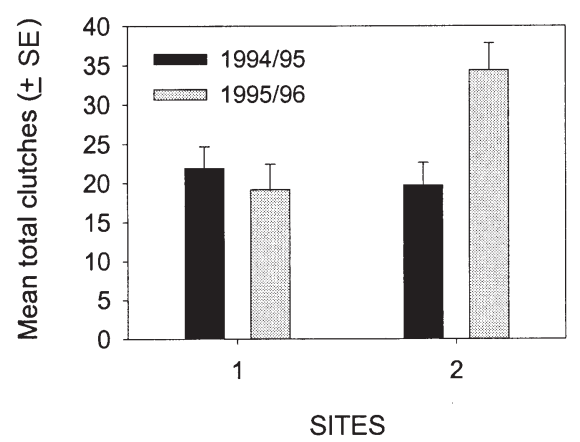

\section{Temperature and tidal amplitude}

Maximum daily water temperature within the lagoon at Ningaloo was not correlated with the variability in number of new clutches laid each day at Tantabiddy. There was only 1 situation where this relationship was significant (albeit weak), which occurred when the number of clutches laid in the second year was lagged by one day (Table 3). There was no significant relationship between water tempera-

b) Bundegi

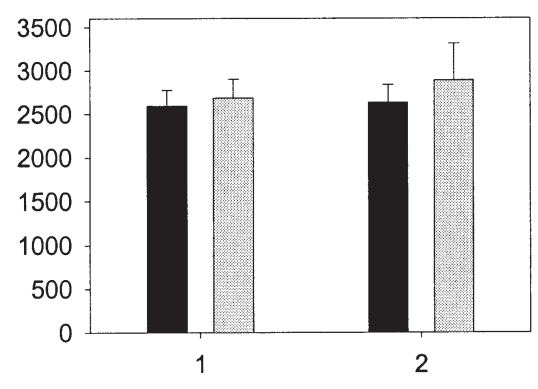

d) Bundegi

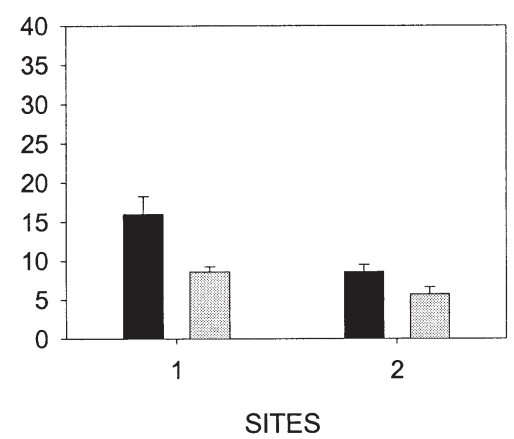

Fig. 3. A comparison of spawning output at each of 2 sites at Tantabiddy and Bundegi for both years represented as (a,b) mean eggs per clutch, and (c,d), as mean total clutches. Bars represent SE. See Table 2 for corresponding repeated measures ANOVA 
ture and egg clutch production during the first summer of sampling.

To correlate tidal height and reproductive output of both populations, I converted the total egg production to total number of larvae by lagging the time series by the average embryonic developmental time of $5 \mathrm{~d}$ (Meekan 1992). The results are consistent at both locations, with all semi-lunar peaks in reproduction coinciding with troughs in tidal amplitude (Figs. 4a,c \& $5 \mathrm{a}, \mathrm{c})$. Although there were large differences in the maximum tidal amplitude between Exmouth Gulf and Tantabiddy (2.0 $\mathrm{m}$ and $1.25 \mathrm{~m}$ respectively), the tidal cycles were correlated when Bundegi was lagged by $1 \mathrm{~d}(\mathrm{r}=0.411$, significant at $2 \times \mathrm{SE}$ at $\operatorname{lag}=1 ; \mathrm{n}=221)$.

When the timing of nocturnal high tides is included in the time series, I discovered that all crepuscular high tides occurred during the lowest tidal amplitude as the cycle moved into the next phase of the spring tides (denoted by the squares in Figs. 4a,c \& 5a,c). When rates of larval production are incorporated, it becomes obvious that most of the larvae hatch during the period when the high tide occurs $2 \mathrm{~h}$ either side of sunset (Figs. 4b,d \& 5b,d). This result is consistent throughout the sampling period at both locations.

\section{The link between production and supply}

The crest nets were successful in capturing presettlement Pomacentrus vaiuli during the transition phase from the pelagic environment to settlement sites within the reef lagoon. Daily sampling over a period of $195 \mathrm{~d}$ allowed me to construct a lengthy time series that showed the periodicity of this arrival was approximately 28 to $30 \mathrm{~d}$. This was confirmed with both spectral analysis and auto-correlation plots. Some peaks in abundance occurred around the new moon periods. There were 5 major settlement events, with 2 in the first year compared to 3 in the second. The total catch of larval $P$. vaiuli in 1995/96 was $20 \%$ less than the previous year even though sampling effort had doubled to 4 nets.

When investigating the potential link between reproductive output and the supply of larvae, the latter was lagged by the average time spent in the plankton (Meekan 1992). The average pelagic duration of $21.8 \mathrm{~d}$ ( $\mathrm{SE}=0.47, \mathrm{n}=20$ ) rounded to $22 \mathrm{~d}$ for Pomacentrus vaiuli was estimated from the otoliths of a combination of presettlement fish caught in light-traps deployed at Bundegi, and juvenile fish collected during the settlement period.

Fig. 6a shows that at Tantabiddy the lunar patterns in larval supply (with a periodicity of approximately $30 \mathrm{~d}$ ) did not match the semi-lunar patterns in larval production. Consequently, the results of the cross-
Table 3. Results of cross-correlation, which compares the percentage of nests with new clutches at Tantabiddy and the daily maximum water temperature. Lag is given in days. *Significant at $2 \times$ SE. Note this only includes data from Tantabiddy and not Bundegi

\begin{tabular}{|lccc|}
\hline Year & \multicolumn{3}{c|}{ Lag } \\
\hline & -1 & 0 & 1 \\
$1994 / 95$ & -0.05 & -0.01 & -0.03 \\
$1995 / 96$ & -0.06 & 0.02 & $0.29^{*}$ \\
& & & \\
\hline
\end{tabular}

Table 4. Summary of the cross-correlation analysis comparing the daily spawning output with lagged larval supply (Tantabiddy) and back-calculated recruitment patterns (Bundegi) for each of the 2 years. - : no significant relationship at any time lag. ${ }^{*}$ Significant at $2 \times \mathrm{SE}_{i} \mathrm{~ns}=$ not significant

\begin{tabular}{|lcccc|}
\hline & \multicolumn{2}{c}{$1994 / 95$} & \multicolumn{2}{c|}{$1995 / 96$} \\
& Lag & $\mathrm{r}$ & Lag & $\mathrm{r}$ \\
\hline Tantabiddy & -1 & $0.30^{*}$ & -4 & $0.27^{*}$ \\
Bundegi & - & $\mathrm{ns}$ & - & $\mathrm{ns}$ \\
\hline
\end{tabular}

correlation analysis were a weak relationship between the 2, at a lag of $1 \mathrm{~d}$ in 1994/95 and a lag of $4 \mathrm{~d}$ in 1995/96 (Table 4). Although both correlations were significant, it is likely that this was due to an artefact of the statistical approach (Olden \& Neff 2001).

At Bundegi, where hatching dates were correlated with spawning output, there was no significant correlation between the 2 time series at any time lag (Table 4). In early January 1995, the hatching of half of the recruits coincided with a time when egg production at Bundegi was minimal (Fig. 6b). The following year over $50 \%$ of the fish collected from Bundegi in 1995/96 were hatched after spawning had stopped following the passing of Cyclone Frank.

\section{DISCUSSION}

This study confirmed that the synchrony, magnitude and timing of spawning of Pomacentrus vaiuli were similar between 2 years and locations with 1 exception. Spawning stopped prematurely at Bundegi when Cyclone Frank passed within $80 \mathrm{~km}$ of the coast in December 1995. For 3 mo after the passing of the cyclone, regular monitoring of the tiles and natural nests revealed no evidence of egg production. Yet recruits of $P$. vaiuli continued to arrive to Bundegi for 2 mo after Cyclone Frank. This suggests that these settlers were not spawned at Bundegi, but instead were the product of a population from somewhere other than Bundegi. 


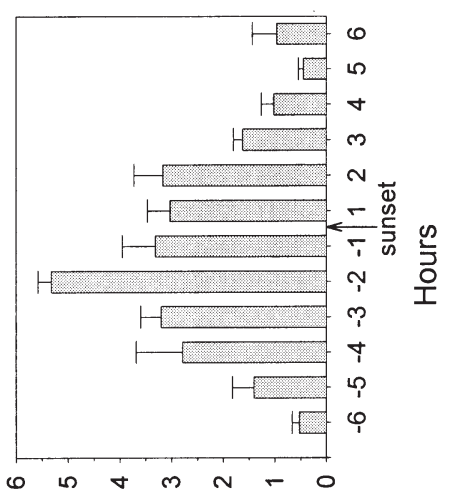

$\widehat{\mathrm{a}}$

$\left({ }_{p} \mathrm{OL}\right)$ әеме „о səqunu ueəW

(แว) $\exists a n \perp l 7 d W \forall 7 \forall a I \perp$

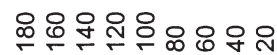

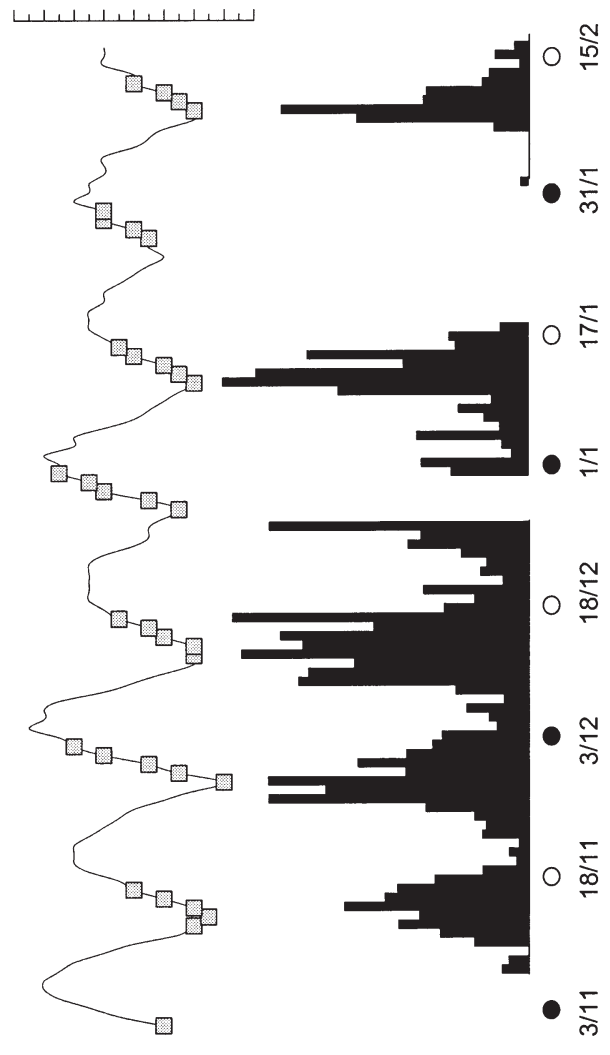

$\widehat{\partial}$

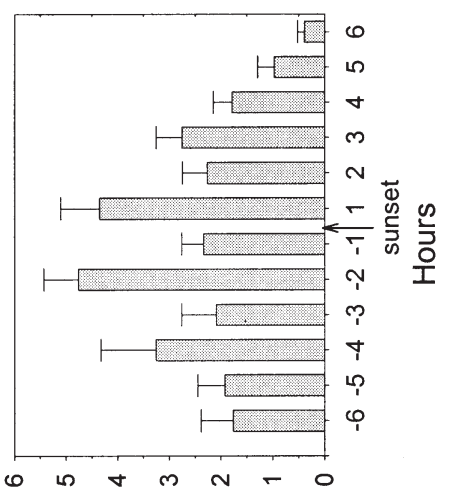

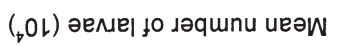

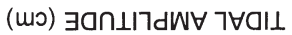

\section{은운꽁용ㅇㅇㅇㅠ}

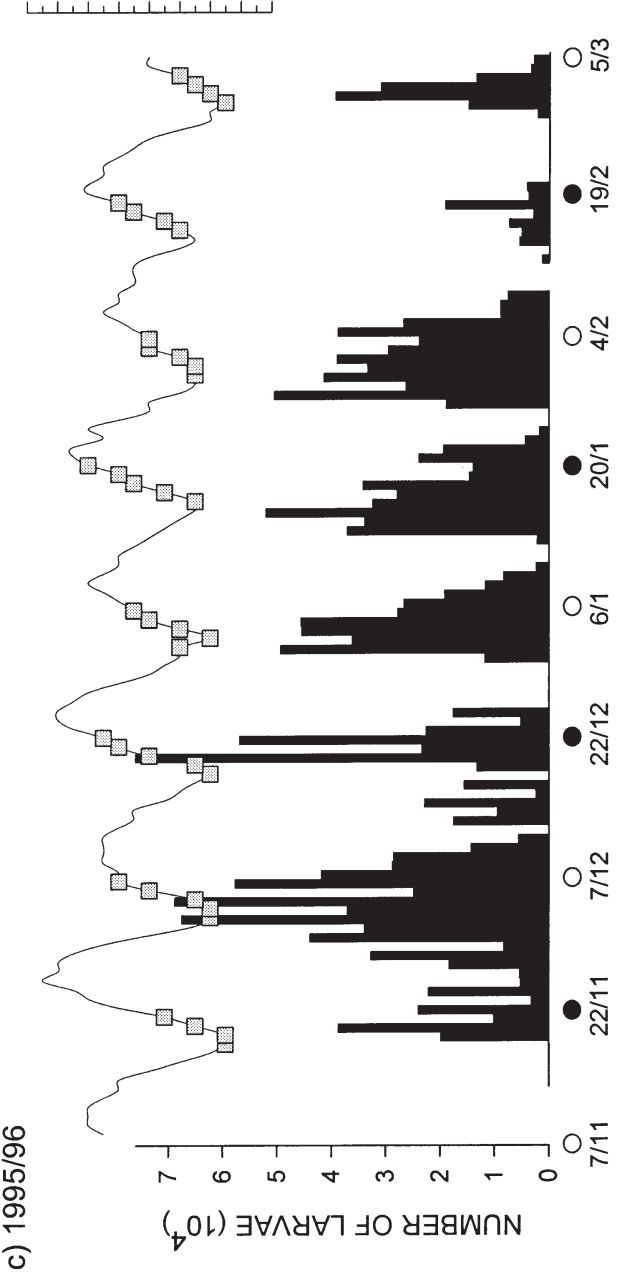

$O \stackrel{2}{N}$

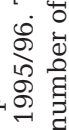

ฮ듀

政

结

家

画

寻

훙형

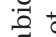

ซี

宅焉

वे

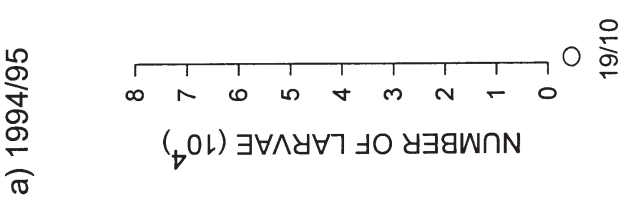

o 


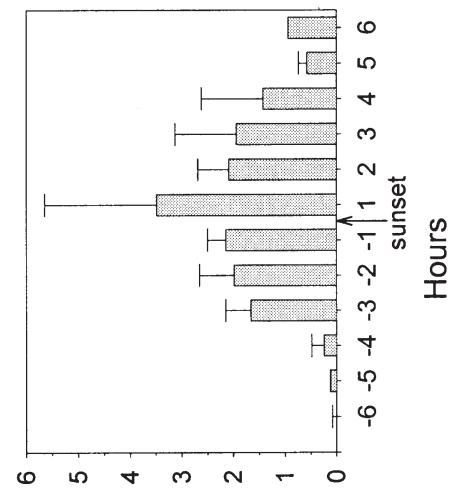

อิ

(wว) $\exists a n \perp า d W \forall$ 7 $\forall a I \perp$
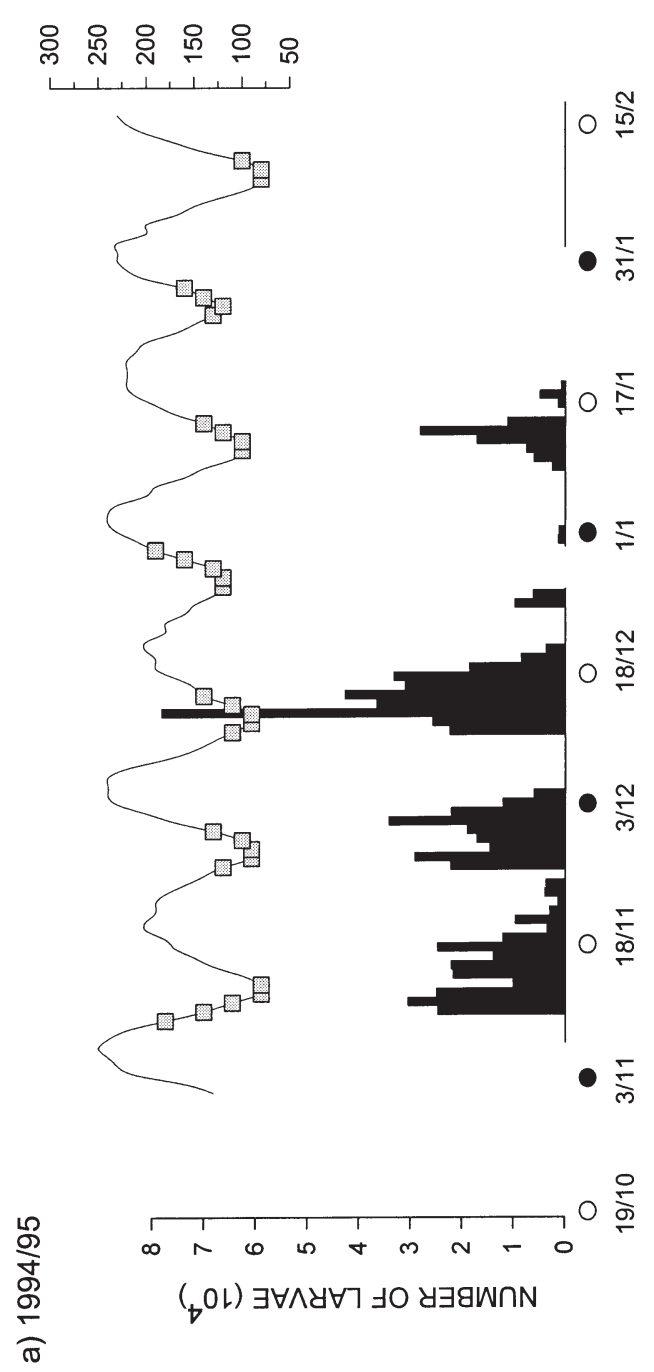

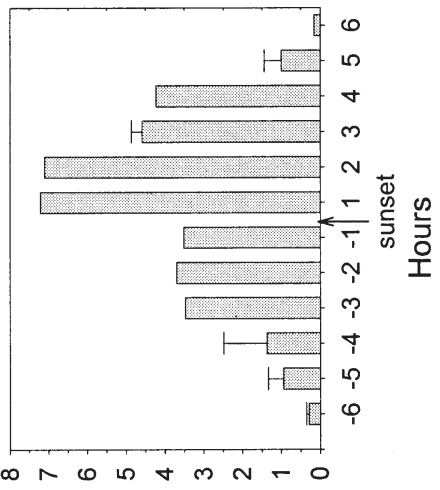

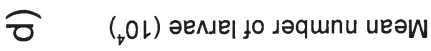

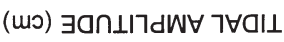
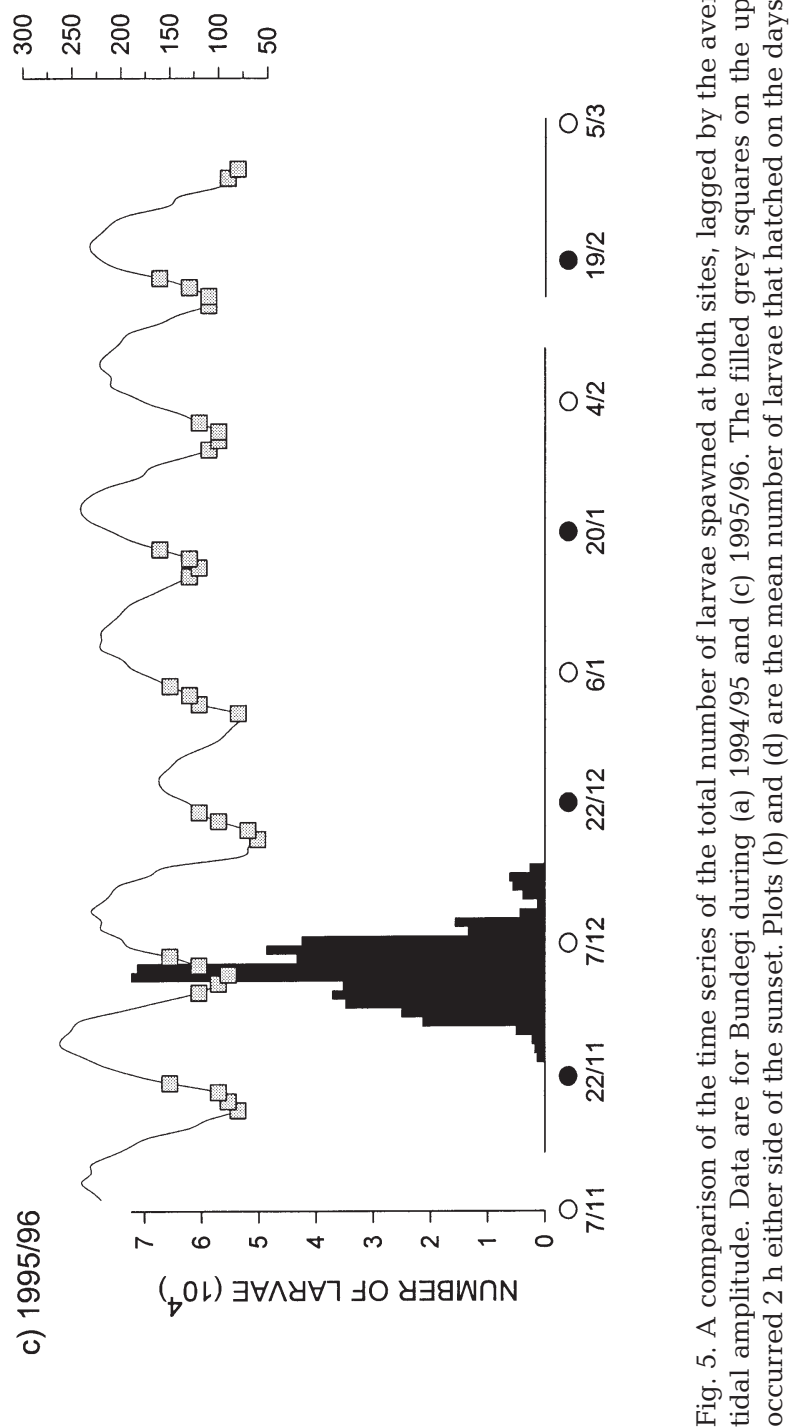
a) Tantabiddy

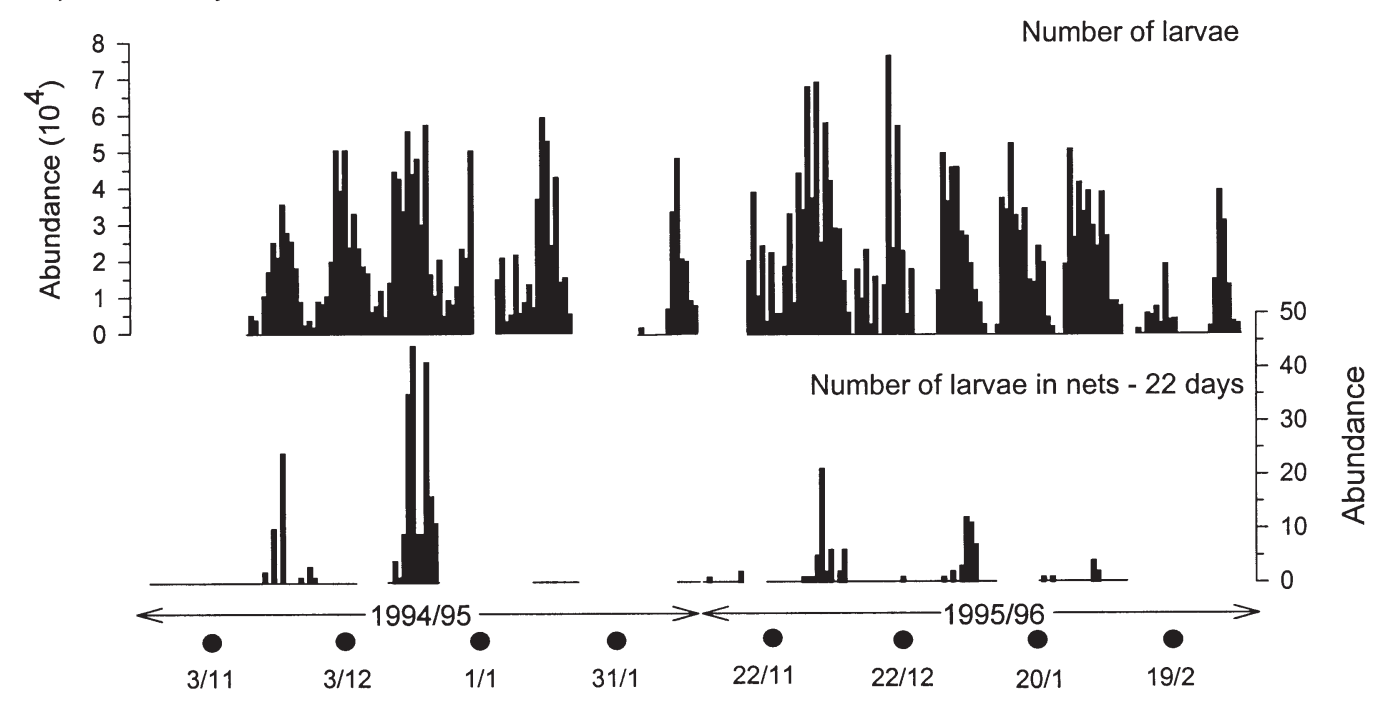

b) Bundegi

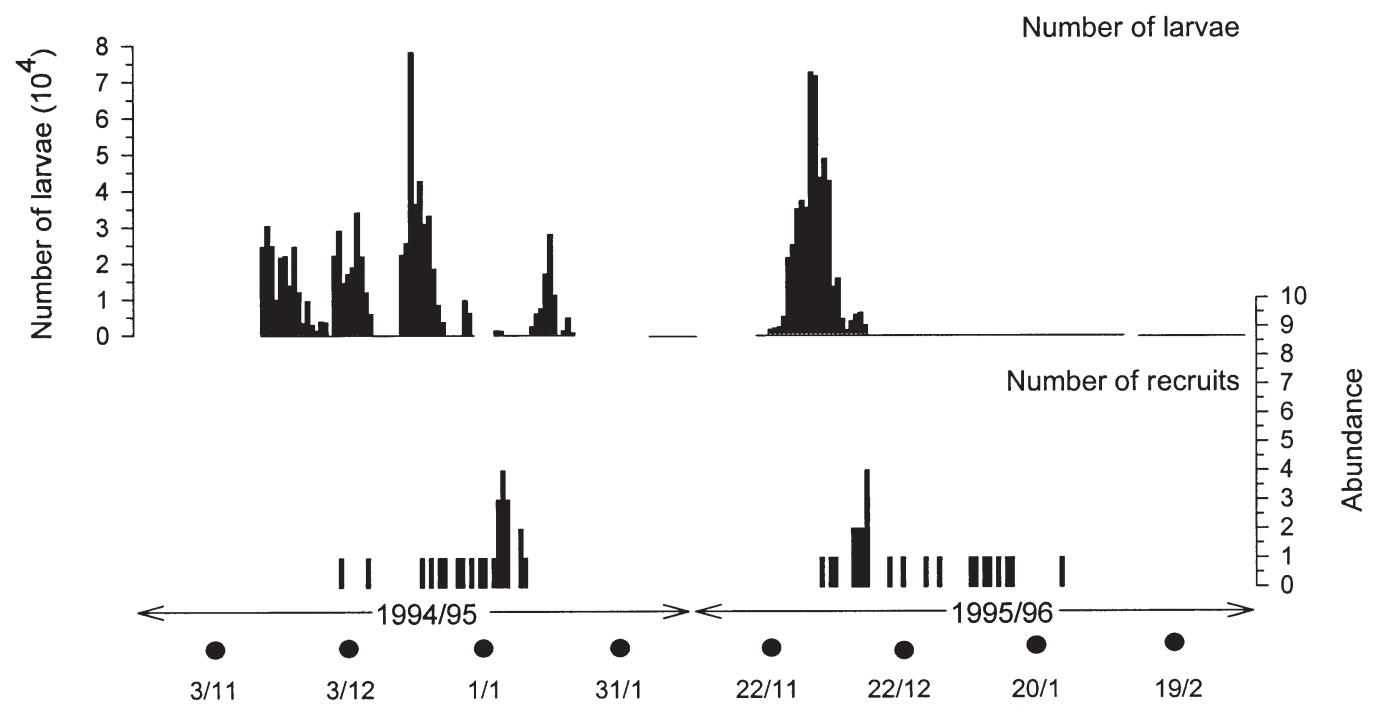

Fig. 6. (a) Comparison between spawning output, represented as total number of larvae (upper panel), with larval supply lagged by $22 \mathrm{~d}$ (lower panel) at Tantabiddy. (b) Comparison between spawning output represented as total number of larvae (upper panel) with the birthdates of recruits (lower panel) at Bundegi. In both figures data have been concatenated. The lunar representation follows that of Fig. 2. Gaps on the $x$-axis are days on which no data were collected

Reproductive output at Tantabiddy and Bundegi was strongly semi-lunar, with peaks in production occurring approximately $3 \mathrm{~d}$ before and $5 \mathrm{~d}$ after the new and full moon periods. The timing of this output was consistent between years. When lagged by the embryonic period of $5 \mathrm{~d}$, these peaks in larval production coincided with periods of crepuscular neap high tides. In contrast to tidal influence, daily fluctuations in lagoonal water temperature had minimal effect on egg production of this species. There was a weak but significant relationship between the timing of spawning and settlement at Tantabiddy indicating peaks in egg production occurred on a semi-lunar cycle whereas peaks in settlement occurred on a lunar cycle.

\section{Temporal patterns in spawning output}

For Pomacentrus vaiuli, the mechanisms responsible for this semi-lunar output in egg production are simple and fit the 'tidal control hypothesis' (Johannes 1978). This suggests that adult fish time the release of larvae to coincide with the window of opportunity in the tidal regime when dispersal is maximised (Johannes 1978, 
Robertson 1991). For example, Ross (1978) found that the number of larval anemone fish Amphiprion melanopus leaving nest sites in Guam peaked when the spring tides occurred shortly after sunset. At Ningaloo cuing into a predictable physical process such as the tide would explain why spawning populations of $P$. vaiuli were both semi-lunar and synchronous between locations (Thresher 1983). However, in contrast to the Guam study, my study found that the release of newly hatched $P$. vaiuli larvae occurred predominantly during the neap tides. In light of these findings, why does $P$. vaiuli release offspring during neap tides when offshore transport is likely to be minimal?

During the spring tidal cycle at Ningaloo, the high tides occur at midnight and midday so that the crepuscular period, when most damselfish larvae hatch (Thresher 1984), is characterised by low tide, a dry reef crest and minimal water movement offshore (Hearn et al. 1986). If Pomacentrus vaiuli larvae hatched during the crepuscular period of the spring tides, they would be trapped in the lagoon for several hours before being transported offshore with the change in tide. During this period of entrapment on the reef they would be at a greater risk of predation. Conversely, during the neap tidal cycle, the highest tides occur around sunset. At Ningaloo Reef, this appears to be the best time for newly hatched $P$. vaiuli larvae to be quickly transported away from the reef. Although the smaller crepuscular neap tides do not maximise the transport of propagules in absolute terms, the trade-off for this species is to disperse larvae to the ocean immediately after hatching in order to minimise predation.

\section{Additional environmental effects on spawning output}

Although the tidal regime determines the timing of spawning for this species, a cyclone-mediated disturbance played a significant role in reducing the egg production and the duration of the spawning season. Very few studies have examined how and why extreme environmental conditions like cyclones and storms suppress spawning in reef fish. A study on the spawning periodicity of temperate species showed that high-intensity, low-frequency storms in New Zealand and the east coast of Australia lead to a short-term disruption in egg production (Tzioumis \& Kingsford 1995). In southern Japan, diurnal spawning in the damselfish Stegastes altus was periodically interrupted by typhoons (Kohda 1988). In all 3 cases these breaks in spawning lasted no longer than $14 \mathrm{~d}$. Only 1 study has recorded longer-term environmental effects on egg production. The reproductive output of the planktivo- rous damselfish Abudefduf saxatalis was interrupted for $8 \mathrm{wk}$, occurring simultaneously in 2 reproductive populations at the San Blas Islands of Panama, following an extended period of abnormally strong winds (Foster 1987). In all cases the authors were unable to ascertain what caused the observed breaks in spawning other than a causal relationship with wind.

Recent studies have shown that the physical factors created by strong wind from cyclones and storms can have a negative effect on reproduction in coral reef fish. Increased wave action, currents and turbidity reduce feeding efficiency and food availability (Clifton 1995, Robertson et al. 1999). For example, Clifton (1995) found a relationship between food availability and egg production in populations of the parrotfish Scarus iserti at a protected reef in Panama. During the dry season, the standing crop of algae increased as did the adult $S$. iserti growth rates and gonad weight: water clarity increased, which resulted in better algal growth. In contrast, during the wet season, algal standing crop declined, as did fish growth and reproduction in response to a decrease in water clarity.

Following the cyclone, the change in environmental conditions at Bundegi was similar to that of Panama during the wet season, where water clarity decreased significantly. The response of adult Pomacentrus vaiuli to these changes was similar if not more dramatic than the response by Scarus iserti. Within $1 \mathrm{~d}$ of the cyclone passing, egg production on the terracotta tiles had stopped completely. This coincided with high levels of suspended sediment in the water column, reducing water visibility to less than $2 \mathrm{~m}$, and this lasted for 4 mo. These conditions would almost certainly affect feeding efficiency and delay reproduction. At the other study site, Tantabiddy, water visibility returned to 'pre-cyclone' levels within $24 \mathrm{~h}$, as did the production of eggs (Fig. 2), which offers corroboration of this interpretation.

An alternative hypothesis is that courtship behaviour was disrupted by the sudden increase in turbidity and the longevity of the highly turbid conditions. This is credible given that visual acuity plays an important role in mate acquisition for most damselfish species (Thresher 1984). However, such a scenario is unlikely because I observed periodic bouts of courtship behaviour after spawning had stopped at Bundegi.

Although there may be other explanations for these results, it is clear that an intense disturbance like a cyclone can have a dramatic effect on the number of larvae that are spawned from a population of coral reef fish. It also led, fortuitously, to an indirect test of whether the larvae returning to the reef were spawned locally or outside the area. Otolith analysis indicated that larvae arriving to the reef could not have been spawned at Bundegi. However, the proportion of 
Bundegi recruitment that is derived locally remains unknown. Further investigation utilising recently developed techniques such as analysis of trace elements in otoliths to determine the degree of dispersal (Swearer et al. 1999, Thorrold \& Shuttleworth 2000) and mark/recapture techniques (Jones et al. 1999) would be enlightening. The regularity and frequency with which high-intensity cyclones occur in this region would certainly enable further information to be collected to test the ideas put forward in this discussion.

\section{The relationship between production and settlement}

The settlement-production model I have described for Pomacentrus vaiuli at Ningaloo fits most closely with that described for Thalassoma bifasciatum, a labrid common throughout the Caribbean. In Panama, Robertson et al. (1999) found that, like the results from this study, the lunar patterns in settlement of $T$. bifasciatum did not match the semi-lunar peaks in larval production. They argued that by advancing or delaying metamorphosis, $T$. bifasciatum larvae avoided settling around the full moon. Evidence supporting this interpretation was that larvae with both short and long pelagic larval duration (PLD) settled as close to the new moon as those with an average PLD. Like the Panama population, T. bifasciatum from Barbados had semi-lunar peaks in production, but the patterns in recruitment were acyclic (Hunt von Herbing \& Hunte 1991). However, it is likely that in this latter study no periodicity was detected because the temporal patterns, constructed using the back-calculation of otoliths, were probably modified through post-recruitment processes (Meekan et al. 1993).

The mismatch between settlement and production seen at Ningaloo is unlikely to be due to plasticity in metamorphosis. Compared to the flexible larval duration of Thalassoma bifasciatum (range $=29$ to $67 \mathrm{~d}$; Robertson et al. 1999), Pomacentrus vaiuli has a relatively inflexible larval duration (range $=16$ to $23 \mathrm{~d}$; Brothers et al. 1983, J. L. McIlwain unpubl. data). It is more likely that a combination of physical and biological oceanographic processes, which influence larval survivorship, behaviour, and feeding, are responsible for the observed decoupling between spawning and supply.

\section{CONCLUSIONS}

Other studies on damselfish have shown a significant link between the timing of spawning and supply. In contrast, I have shown that in 1 species over 2 spawn- ing seasons, there is no such relationship. This study is one of the few to show that major disturbance events like cyclones can have a detrimental effect on the reproductive output of a coral-reef fish. This raises some interesting questions for future research, such as: What impact does spawning failure have on the magnitude of settlement, particularly if it occurred on a large, reef-wide scale? Is this failure to spawn following a cyclone event limited to benthic spawners such as damselfish, or are broadcast spawners like labrids and scarids affected in the same way? Knowing the answer to these questions is particularly pertinent given that NW Australia has the greatest frequency of high-intensity cyclones in the southern hemisphere (Callaghan 1997), and the La Niña cycles, responsible for increased cyclone activity in this region, are set to increase with the predicted onset of global warming. Finally, the passing of a cyclone offered a unique opportunity to investigate the degree of openness in the Bundegi population. Future research in this area should set out to quantify the proportion of recruits that come from both local and non-local sources during summer periods when there is no cyclone activity.

Acknowledgements. The number of people who gave generously of their time during the field component of this project is too large to mention each one individually, but I extend my thanks to all of them. I am especially grateful to Andrew Halford and John Carleton for reviewing earlier drafts of this manuscript, Peter Doherty and Bob Black for their insight and guidance, and Peter Speare for help with compiling the tidal data. The tidal predictions for Exmouth Gulf and Tantabiddy were supplied by the National Tidal Facility at Flinders University of South Australia, copyright reserved. This research was supported by the Australian Institute of Marine Science (AIMS) and the University of Western Australia (UWA). This is AIMS Publication No. 1111.

\section{LITERATURE CITED}

Babcock RC (1995) Synchronous multispecific spawning on coral reefs: potential for hybridisation and roles of gamete recognition. Invertebr Reprod Dev 7:943-950

Babcock RC, Bull GD, Harrison PL, Heyward AJ, Oliver JK, Wallace CC, Willis BL (1986) Synchronous spawnings of 105 scleractinian coral species on the Great Barrier Reef. Mar Biol 90:379-394

Brothers EB, Williams DM, Sale PF (1983) Length of larval life in twelve families of fishes at One Tree Lagoon, Great Barrier Reef, Australia. Mar Biol 76:319-324

Callaghan J (1997) The south Pacific and southeast Indian Ocean tropical cyclone season 1995-96. Aust Met Mag 46: 325-339

Chatfield C (1980) The analysis of time series: an introduction. Chapman \& Hall, London

Clifton KE (1995) Asynchronous food availability on neighboring Caribbean coral reefs determines seasonal patterns of growth and reproduction for the herbivorous parrotfish Scarus iserti. Mar Ecol Prog Ser 116:39-46

Danilowicz BS (1995a) Spatial patterns of spawning in the 
coral reef damselfish Dascyllus albisella. Mar Biol 122: $145-155$

Danilowicz BS (1995b) The role of temperature in spawning of the damselfish Dascyllus albisella. Bull Mar Sci 57: $624-636$

Danilowicz BS (1997) A potential mechanism for episodic recruitment of a coral reef fish. Ecology 78:1415-1423

de Boer BA (1978) Factors influencing the distribution of the damselfish Chromis cyanea (Poey), Pomacentridae, on a reef at Curacao, Netherlands Antilles. Bull Mar Sci 28: $550-565$

Doherty PJ (1983) Diel, lunar and seasonal rhythms in the reproduction of two tropical damselfishes: Pomacentrus flavicauda and P. wardi. Mar Biol 75:215-224

Doherty PJ (1987) Light-traps: Selective but useful devices for quantifying the distributions and abundances of larval fishes. Bull Mar Sci 41:423-431

Doherty PJ (1991) Spatial and temporal patterns in recruitment. In: Sale PF (ed) The ecology of fishes on coral reefs. Academic Press, San Diego, p 261-293

Doherty PJ, McIlwain JL (1996) Monitoring larval fluxes through the surf zones of Australian coral reefs. Mar Freshw Res 47:383-390

Dufour V, Galzin R (1993) Colonization patterns of reef fish larvae to the lagoon at Moorea Island, French Polynesia. Mar Ecol Prog Ser 102:143-152

Foster SA (1987) Diel and lunar patterns of reproduction in the Caribbean and Pacific sergeant major damselfishes Abudefduf saxatilis and A. troschelii. Mar Biol 95:333-343

Hearn CJ, Hatcher BG, Masini RJ, Simpson CJ (1986) Oceanographic processes on the Ningaloo coral reef, Western Australia. University of Western Australia Environmental Dynamics Report, Department of Conservation and Land Management, Perth, p 1-79

Hunt von Herbing I, Hunte W (1991) Spawning and recruitment of the bluehead wrasse Thalassoma bifasciatum in Barbados, West Indies. Mar Ecol Prog Ser 72:49-58

Johannes RE (1978) Reproductive strategies of coastal marine fishes in the tropics. Environ Biol Fish 3:65-84

Jones GP, Milicich MJ, Emslie MJ, Lunow C (1999) Selfrecruitment in a coral reef fish population. Nature 402: 802-804

Kerrigan BA (1997) Variability in larval development of the tropical reef fish Pomacentrus amboinensis (Pomacentridae): the parental legacy. Mar Biol 127:395-402

Kingsford MJ, Finn MD (1997) The influence of phase of the moon and physical processes on the input of presettlement fishes to coral reefs. J Fish Biol 51:176-205

Kohda M (1988) Diurnal periodicity of spawning activity of permanently territorial damselfishes (Teleostei: Pomacentridae). Environ Biol Fish 21:91-100

Leis JM, Rennis DS (1983) The larvae of Indo-Pacific coral reef fishes. New South Wales University Press, Sydney, and University Hawaii Press, Honolulu

Leis JM, Trnski T (1989) The larvae of Indo-Pacific shore fishes. New South Wales University Press, Sydney, and University Hawaii Press, Honolulu

McIlwain JL (1997) Hydrodynamic flows and the flux of larval fishes across the crest of Ningaloo Reef, Western Australia. Proc 8th Int Coral Reef Symp, Panama 2:1133-1138

Meekan MG (1992) The influence of pre- and post-settlement processes on the population dynamics of coral reef damselfishes. PhD thesis, Griffith University, Brisbane

Meekan MG, Milicich MJ, Doherty PJ (1993) Larval production drives temporal patterns of larval supply and recruitment of a coral reef damselfish. Mar Ecol Prog Ser 93: $217-225$
Milicich MJ (1992) Light traps: a novel technique for quantifying larval supply and replenishment of coral reef fish populations. PhD thesis, Griffith University, Brisbane

Milicich MJ (1994) Dynamic coupling of reef fish replenishment and oceanographic processes. Mar Ecol Prog Ser 110:135-144

Moyer JT, Thresher RE, Colin PL (1983) Courtship, spawning and inferred social organization of American angelfishes (genera Pomacanthus, Holacanthus and Centropyge; Pomacanthidae). Environ Biol Fish 3:25-39

Olden JD, Neff BD (2001) Cross-correlation bias in lag analysis of aquatic time series. Mar Biol 138:1063-1070

Pitcher CR (1988) Validation of a technique for reconstructing daily patterns in the recruitment of coral reef damselfish. Coral Reefs 7:105-111

Pitcher CR (1992) Growth of juvenile coral reef damselfish: spatial and temporal variability, and the effect of population density. Aust J Mar Freshw Res 43:1129-1149

Robertson DR (1990) Differences in the seasonalities of spawning and recruitment of some small neotropical reef fishes. J Exp Mar Biol Ecol 144:49-62

Robertson DR (1991) The role of adult biology in the timing of spawning of tropical reef fishes. In: Sale PF (ed) The ecology of fishes on coral reefs. Academic Press, San Diego, p 356-386

Robertson DR, Green DG, Victor BC (1988) Temporal coupling of production and recruitment of larvae of a Caribbean reef fish. Ecology 69:370-381

Robertson DR, Petersen CW, Brawn JD (1990) Lunar reproductive cycles of benthic-brooding reef fishes: reflections of larval biology or adult biology? Ecol Monogr 60: $311-329$

Robertson DR, Swearer SE, Kaufman K, Brothers EB (1999) Settlement vs environmental dynamics in a pelagicspawning reef fish at Caribbean Panama. Ecol Monogr 69:195-218

Ross RM (1978) Reproductive behaviour of the anemonefish Amphiprion melanopus on Guam. Copeia 1:103-107

Schmale MC (1981) Sexual selection and reproductive success in males of the bicolor damselfish, Eupomacentrus partitus (Pisces: Pomacentridae). Anim Behav 29:1172-1184

Shenker JM, Maddox ED, Wishinski E, Pearl A, Thorrold SR, Smith N (1993) Onshore transport of settlementstage Nassau grouper Epinephelus striatus and other fishes in Exuma Sound, Bahamas. Mar Ecol Prog Ser 98: $31-43$

Shepard IJ, Bate PW (1997) The south Pacific and southeast Indian Ocean tropical cyclone season 1994-95. Aust Met Mag 46:143-151

Simpson CJ (1991) Mass spawning of corals on Western Australian reefs and comparisons with the Great Barrier Reef. J R Soc West Aust 74:85-91

Sponaugle S, Cowen RK (1996) Nearshore patterns of coral reef fish larval supply to Barbados, West Indies. Mar Ecol Prog Ser 133:13-28

Stanton FG (1985) Temporal patterns of spawning in the demersal brooding blackspot sergeant Abudefduf sordidus (Pisces: Pomacentridae) from Kaneohe Bay (Hawaii). Proc 5th Int Coral Reef Congr, Tahiti 5:361-366

Swearer SE, Caselle JE, Lea DW, Warner RR (1999) Larval retention and recruitment in an island population of a coral-reef fish. Nature 402:799-802

Thorrold SR, Milicich MJ (1990) Comparison of larval duration and pre- and post-settlement growth in two species of damselfish, Chromis atripectoralis and Pomacentrus coelestis (Pisces: Pomacentridae), from the Great Barrier Reef. Mar Biol 105:375-384 
Thorrold SR, Shuttleworth S (2000) In situ analysis of trace elements and isotope ratios in fish otoliths using laser ablation sector field inductively coupled plasma mass spectrometry. Can J Fish Aquat Sci 57:1232-1242

Thorrold SR, Shenker JM, Maddox ED, Mojica R, Wishinski E (1994) Larval supply of shorefishes to nursery habitats around Lee Stocking Island, Bahamas. II. Lunar and oceanographic influences. Mar Biol 118:567-578

Thresher RE (1983) Habitat effects on reproductive success in the coral reef fish, Acanthochromis polyacanthus (Pomacentridae). Ecology 64:1184-1199

Thresher RE (1984) Damselfishes (Pomacentridae). In: Thresher RE (ed) Reproduction in reef fishes. TFH Publications, Hong Kong, p 180-226

Tyler WA, Stanton FG (1995) Potential influence of food abun-

Editorial responsibility: Otto Kinne (Editor),

Oldendorf/Luhe, Germany dance on spawning patterns in damselfish, Abudefduf abdominalis. Bull Mar Sci 57:610-623

Tzioumis V, Kingsford MJ (1995) Periodicity of spawning of two temperate damselfishes: Parma microlepis and Chromis dispilus. Bull Mar Sci 57:596-609

Vigliola L, Harmelin-Vivien M, Meekan MG (2000) Comparison of techniques of back-calculation of growth and settlement marks from the otoliths of three species of Diplodus from the Mediterranean Sea. Can J Fish Aquat Sci 57: 1291-1299

Wilson DT, McCormick MI (1997) Spatial and temporal validation of settlement-marks in the otoliths of tropical reef fishes. Mar Ecol Prog Ser 153:259-271

Zar JH (1996) Biostatistical analysis. Prentice-Hall International, London

Submitted: February 7, 2001; Accepted: February 19, 2002 Proofs received from author(s): May 21, 2002 